\title{
Haddad syndrome
}

INSERM

\section{Source}

INSERM. (1999). Orphanet: an online rare disease and orphan drug data base. Haddad syndrome. ORPHA:99803

Haddad syndrome is a rare cong enital disorder in which congenital central hypoventilation syndrome (CCHS), or Ondine syndrome, occurs concurrently with Hirschsprung disease (see these terms). 